\title{
ANTONIO DE ULLOA, DISCOVERER OF PLATINUM
}

\author{
Lavine 1 G. Ionescu \\ Departamento de Química Pura, Faculdade de Química \\ Pontificia Universidade Catōilica do Rio Grande do Sul-PUCRS \\ Porto Alegre, RS BRASIL 90610-900 \\ \& \\ Departamento de Quĩmica, Centro de Ciências Naturais e Exatas \\ Universidade Luterana do Brasil - ULBRA \\ Canoas, RS BRASIL $92420-280$
}

\begin{abstract}
Don Antonio de ULZoa, member of a distinguished spanish family, was born in 2726 and died in 7795 . He studied. physics and mathematics and was a member of many scientific societies, including the Academy of sciences of Paris and the Royal Society of London. He travelled widely in Europe and the Americas and occupied many important positions, including those of Frigate Captain, Commander of the Royal Squadron of the Spanish Armada, Governor of Huancaverica Peru, Louisiana and Floxida. In 2735, while member of a scientific expedition sent by the Spanish and French governments to South America to measure a degree of meridian in Quito, close to the equator, he discovered platinum in the mines of Lavadero or wash gold in the district of Choco.
\end{abstract}

\section{RESUMO}

Don Antonio de UZZoa, membro de uma ilustre familia espanhola, nasceu em 7726 e morreu em 7795 . Ele estudou fisica e matemática e foi sócio de muitas entidades cientificas, incluindo a Academia de Ciências de paris e a Royal Society de Londres. Viajou extensivamente na Europa e nas Américas e ocupou muitos cargos importantes, entre eles, capitão de Eragata, Comandante da Esquadra da Real Armada Espanhola, Governador de Huancavélica - Peru, da Louisiana e da Flórida. Em 2735, quando fazia parte de uma expedicão cientifica enviada pelos governos da Espanha e da Frangà à América do Sul para medir um arco de meridiano em Quito, perto do ecuador, descobriu a platina nas minas de Lavadero no partido de Chocó.

KEYWORDS History of Chemistry, Platinum, Discovery of the Elements. 
Contrapily to what is generally belieyed, many scientists that were born or lived in Latin America, made significant contributions to chemistry. Among them are Antonio de U1 loa $(1716-1795)$, who was the first to take platinum to Europe and make this metal known in the 01d World; Fausto and Juan Jose Delhuyar, discoverers of tungsten; Andrês Manuel Del Rio, discoverer of vanadium; Jose Luis Casaseca, founder of the Cuban Institute of Chemical Research; Alyaro Reynoso, father of modern sugar technology and Luis Frederico Leloir, Nobel laureate in chemistry. Notable contributions were al so made by Horacio Damianovich in noble gas chemistry, Gustayo Fester and Xorge Alejandro Dominguez in natural products and Ernesto Giesbrecht in the chemistry of lanthanides.1-10 More recently, in 1995, the Mexican chemist Mario Molina was awarded the Nobel Prize in Chemistry together with Paul Crutzen and F. Sherwood Rowland for their work dealing with the ozone layer.

Antonio De Ulloa, member of an illustrious Spanish family, was born in Seyille in 1716 and died on the Island of Leon near Cadiz on July 5, 1795. He received a very good formal education and turned out a brilliant young physicist and mathematician. His first long travel was at the age of thirteen, when he participated in an expedition to Cartagena de Indias (Carthagena, Colombia). Upon his return to Cadiz in 1732 , after passing successfully a series of examinations, he entisted as a naval guard.

In 1735 the Academy of Sciences of Paris nominated two scientific commissions to perform measurements of degrees of meridians. The first one, that travelled to Lapland and was to make measurements near the North Pole was headed by Louis Moreau de Maupertuis (1698-1759) and the Swedish scientist Anders Celsius (1701-1744). The second one, formed by charles Marie La Condamine (1701-1774), Louis Godin (1704-1760) and Pierre Bouguer (1698-1758) was sent to Peru and Ecuador to measure a degree of meridian near Quito, close to the equator. $11-77$

Louis $X V$ solicited an authorization from Philip $V$, king of Spain, who not anly gave approyal and support, but also appointed two young officers (Frigate Lieutenants) of the Spanish Armada to accompany the French Commission, assist with the observations and measurements and help obtain new scientifjc knowledge about the shape and the dimensions

The two young nayal officers were Jorge Juan Santacilia (1713-1773) and Juan Antonio De Ulloa. The two left Spain in May 1735 and arriyed in Cartagena on july 1 , where they met the French scientists. They travelled together to Portobelo, Guayaquil and Quito and collaborated doing various types of astronomical measurements and observations. Ulloa worked mainly with La Condamine and Bouguer. Soon afterwards, in May 1736, the two young Spanish officers received secret military assignments and classified scientific tasks from the Viceroy of Peru that they performed for about eight years, when they 
returned to Quito and engaged in astronomical observations at the Pueblo Viejo de Mira observatory. Part fo the discoveries and observations made during the nine years of exploration have been described in the monumental work published by the two of them in Madrid in 1748. This work also includes the first description of platinum given below. 14

"En el Partido del Chocó, habiendo muchas minas de Lavadero, como las que se acaban de explicar, se encuentran también algunas, en donde por estar disfrazado, y envuelto el Oro, con otros cuerpos metálicos, Jugos y Piedras, necesita para su beneficio el auxilio del Azoguc; y tal vez se hallan minerales, donde la Platina (Piedra de tanta resistencia, que no es fácil romperla, ni desmenuzarla con la fuerza del golpe sobre Yunque de Acero), es causa de que se abandonen; porque ni la calcinación la vence, ni hay arbitrio para extraer el Metal que encierra, sino a expensas de mucho trabajo y costo" *.*.

\footnotetext{
* * Relactón Hist6rica del Viaje a la Amertca Meridional hecho de orden de S. Mas. pana medtr alsunos srados del meridlano terrestre y venir por ellos en conoclmiento de la verdadera fisura y magnitud de ta Tietra, con otras oberrusclones cstronomicas y fisicas: Pox Don Jorge Juan, Comendador de Allaza en el Orden de San Juan, tocio correspondiente de la Real Academin de Ciencias de París y Don Juan Antonio de Ulloa, de la Real Sociedad de Londres: Ambos capitanes de Frazats de la Armada. Impresa de orden del Rey Nuestro Señor en Madrid por Aatonlo Marín. Año de MDCCXLVIII Primera Parte Tomo II p. 606.
}

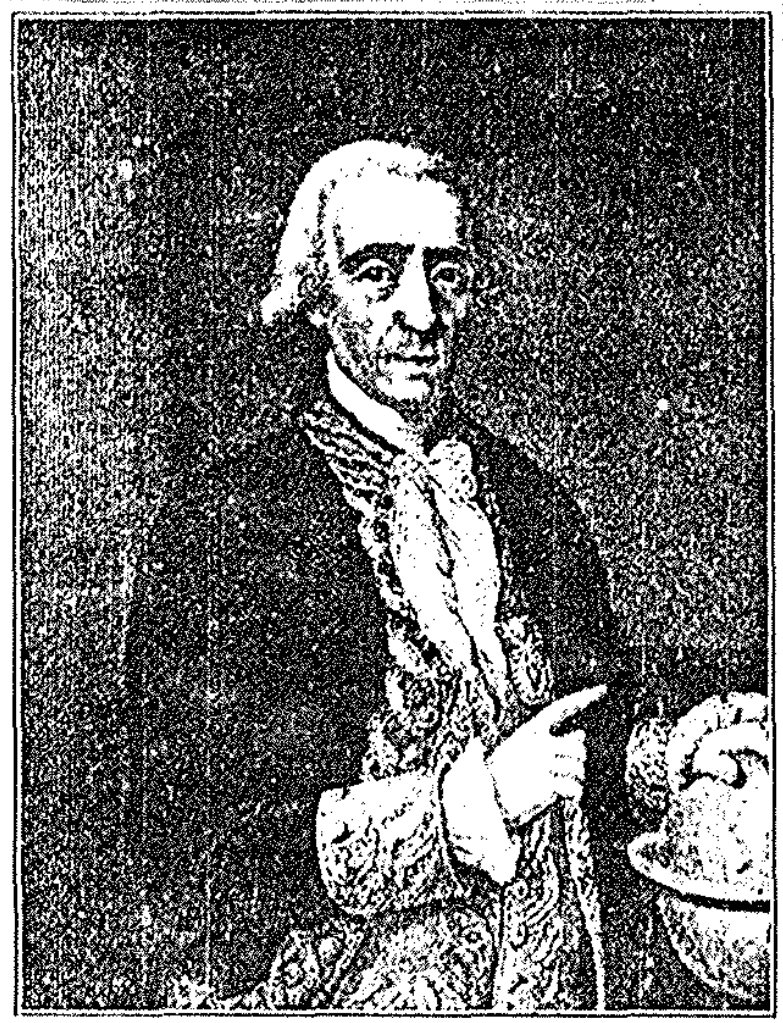

\section{ANTONIO DE ULLOA (1716-1796)}

SPANISH PHYSICIST, MATHEMATICIAN, NAVAL COMMANDER, DISCOVERER OF PLATINUM, GOVERNOR OF LOUISIANA AND FLORIDA, EXPLORER OF THE AMERICAS. 
Mary Elvira Weeks in her book "Discovery of the EZements" 18 states the following:

In the preface to

his "Astronomical and Physical Observations," Jorge Juan said that Ulloa regarded platinum as a peculiar metal and anticipated that there must be special mines of it just as there are of gold and silver."

De Ulloa described it as follows: "In the district of Chocd are many mines of Lavadero, or wash gold ... several of the mines have been abandoned on account of the platina; a substance of such resistance that, when struck on an anvil of steel, it is not easy to be separated; nor is it calcinable; so that the metal, inclosed within this obdurate body, could not be extracted without infinite labour and charge...

Apparently, the discovery of platinum in the district of Choco on the Pacific Coast of present day Colombia occurred in 1735, during the initial part of the expedition from Cartagena to Quito and both scientists were very much aware of its importance.11

In May of 1745, after ecmpleting the military and scientific missions, the two officers made arrangements to return to spain. In order to avoid the risk of 100 sing the results of the scientific work, they embarked separately and Jorge Juan arriyed safely in Europe. On the other hand, Antonio De Ulloa travelled on the French frigate Dézivrance that was captured by the British. Some of the more compromising documents in De Ulloa's possession were thrown in the sea; the rest were confiscated by the British and he was made prisoner. He only returned to Madrid on July 25, 1746. Apparently, he was treated well and was presented to Martin Folkes, president of the Royal Society. When he petitioned the Admiralty for the return of his papers, the Duke of Bedford affirmed that war between nations should not hinder the progress of science and he was allowed to travel to London and receive back his documents.11,18

After his return to Spain, De Ulloa did not devote much effort to platinum. The studies were continued by Fausto Delhuyar (1755-1833) and Pierre Francois Chabaneau (1754-1842) and gave Spajn a practical monopoly of this metal for many years.11-13

Besides the British, many other scientists became interested in platinum. They included Scheffer, Bergman, Berzelius, Baumé, Buffon, Layoisier, Macquer, Marggraf and others.

Antonio De Ulloa devoted his time to other activities. He travelled widely in Europe on scientific missions. For example, in 1755, he visited Sweden and was elected member of the Swedish Academy. He reorganized the teaching of medicine in Spain, established the textile industry, improved the arsenals and the mining of mercury. In 1758 he was named Governor of Huancayêtica, Peru and superintendent of the mercury mines. In 1765 he was named Governor of Louisiana, in 1766 Governor of Florida and in 1772 Commander of the Spanish Fleet.19-21 
In 1750 , Brownrigg sent a sample of a mineral containing "P.Zatina di Pinto" to Sir William Watson of the Royal Society. Brownrigg had obtained the sample from the metallurgistli, 8 Charles Wood during a trip to Jamaica, West Indies. It was contraband from Carthagena, Colombia. Sir William Hatson analyzed the sample and presented the results to the Royal Society on December 13, 1750. A copy of the page of the Philosophical Transactions Abridgement containing Watson's communication and Brownrigg's letter is given below.

XXXIII. 1. I take the freedom to inclofe to you an account of a scrisal for femi-metal called Platina di $P$ into; which, fo far as I know, hath notpers concers:been taken notice of by any writcr on mincrals. Mr Hill, who is one ins a now : of the moft modern, makes no mention of it. Prefuming therefore that semi Metal, the fubject is new, 1 requeft the favour of you to lay this account before comminicased the $R$. S to be by them read and publined, if they think it deferving sose Royal thofe honours. I Thould fooner have' publifhed this account but wait- Society by Mred, in hopes of finding leifure to make further experiments on this body Wm. Watfon,

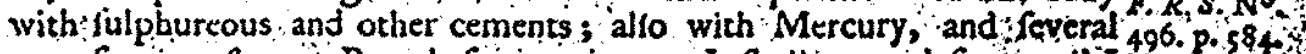
corrofive menftrua. But thefe experiments I. Shall now defer, until I Nor. \&s. learn how the above is received. The experiments which thaye related $17500^{\prime}$ Read $t$ were feveral of them made by: a friend, whofe exactnets in performing Dee.13,1750 them, and veracity in relating them, I can rely on, how ever, for grea Lxtrat of

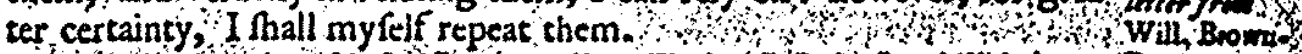

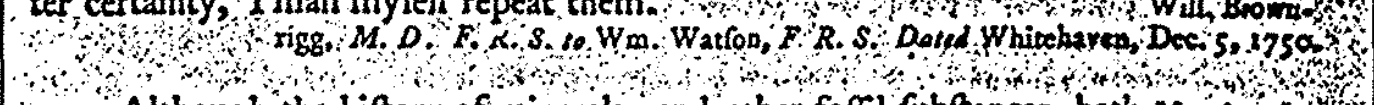

2. Although the hiftory of minerals, and other folfil fubftances, hath Mrimive of been diligently cultivated, efpecially by the Moderns in yet it muft be Sewi-estal acknowledged, that among the valt variety of bodies which are the dalled Platina objects of that fcience; there ftill temains room for new inquiries on dipinto; faxd

No wonder that, among the great, and almolt inexhauftible, variectes Wef indies, of fales, ores, and other concretes, new appearances, and mixtures bo- Ibid p. 585 . fore unknown, hould daily be difcovered : but that, among bodjes of a more fimple nature, and particularly among the metalline, tribe, forcral ditinet fpecies hould ftill remain almolt wholly unknown to Natw

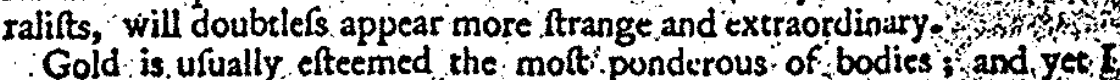
have feen, in the pofferion of the'late Profeffor s'Gravefande, a metal, line fubltance, brought from the Eaft, Indies, that was fpecifically hea

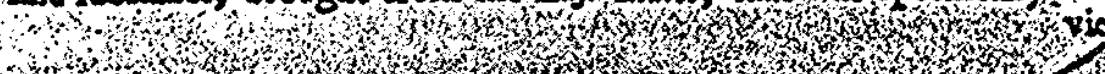

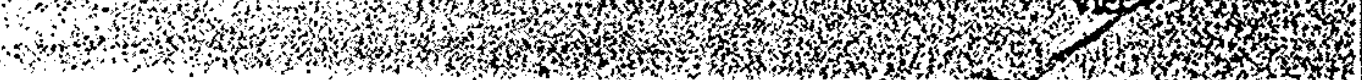

In many chemistry books written in English, Sir William Watson is considered the sole and exclusive discoverer of platinum. 
SOUTH. BRAZ. J. CHEM., Vol. 6, No 7, 1998

Antonio De UlZoa, Discoverer of Platinum

\section{REFERENCES}

1. M. Roche, Science, 294, 806 (1976).

2. G. Weinberg, Interciencia, 3(2), 72 (1978).

3. J. A. Schufle and L. G. Ionescu, J. Chem. Educ., 53, 174 (1976).

4. L. G. Ionescu and J. A. Schufle, J. Chem. Educ.,55,583 (1978).

5. L. G. Ionescu and J. A. Shufle, N. Mex. J. Science, 2I(1), 41 (1978).

6. L. G. Ionescu, R. A. Yunes and J. A. Schufle, J. Chem. Educ., $59,304(1982)$.

7. L. G. Ionescu, R. A. Yunes and J.A. Schufle, N. Mex. Highiands Univ. J., 4(1), 32 (1983).

8. L. G. Ionescu, South. Braz. J. Chem., 2, 1 (1994).

9. L. G. I onescu and C. A. Perazzolo, South Braz. J. Chem., 3, 1 (1995).

10. L. G. Ionescu, South. Braz. I. Chem.,4, 1 (1996).

11. R. Osorio 0., "Historia de Za Quimica en Colombia", Publ. Geo7. Esp., Ingeminas, Bogotá, Colombia, 1982.

12. M Bargal1o," "La Amalgamación de los Minerales de Plata en Hispanoamérica Colonial", Compañia Fundidora de Fierro y Acero de Monterrey, Mexico, D.F., 1969.

13. M. Bargal1ó, La Mineria y Metalurgia en ia América Española durante la Epoca Colonial". Fondo de Cultura Económica, Mexico, D.F., 1955.

14. J. Jorge and J. A. De Ulloa, "ReZación Histórica del Viaje a la América Meridional hecho de orden de S. Mag. para Medir Algunos Grados del Meridiano Terrestre y Venir por ElZos en Conocimiento de la Verdadera: Figura y Magnitud de la Tierra, con otras observaciones Astronómicas $y$ Fisicas", Antonio Marin, Madria, 1748.

15. J. Jorge and A. De U17oa, "A Voyage to South America", Vols. 1,2, Lockyer Dayis, London, 1772 .

17. C.M. La Condamine, "Relation abregée d'un voyage fait dans Z'interieur de l'Amérique Meridionale", Paris, 1745.

18. M. E. Weeks, "Discovery of the Elements", Published by Journal of Chemical Education, Easton, Pa., USA, 1945.

19. A. Phelps, "Louisiana, a Record of Expansion", Houghton, Mifflin and Company, Boston, 1903.

20. A. De Ulloa, "Relacion circunstanciada del gobierno y superintendencia de la Real Mina de Azougues de la Vila de Guancavélica por el capitan de la Real Armada, desde el 4 de noviembre de 2758 hasta el 74 de mayo de $2762 "$, Guancavēlica, 1762 .

21. A. De Ulloa, "Noticias americanas. Entretenimientos fisicohistóricos sobre América Meridional y Septentrional oriental, climas y producciones en las tres especies vegetales, animales y minerales", Madrid, 1772. 